\title{
The Relationship of Teacher's Competence and Performance in Sports Physical Education and Health in Implementing 2013 Curriculum at SMP in Solok Regency
}

\author{
Ruki Febri Hartika*, Bafirman, Alex Aldha Yudi \\ Sport Science Faculty, Universitas Negeri Padang, Prof. Dr.Hamka, Padang, Indonesia \\ *Corresponding author. Email: rukifebrihartika14@gmail.com
}

\begin{abstract}
Problems during the learning process of Physical and Sports Education are estimated to be caused by teacher performance. This study aims to analyze the relationship of professional competence with the performance of PJOK teachers, pedagogic competence with PJOK teacher performance, professional competence,pedagogic with PJOK teacher performance. This type of research is correlational, he population in this study were PJOK teachers at Solok City Middle School, sampling techniques using saturated sampling totaling 19 people. Data were collected using a Likert scale questionnaire to measure pedagogic competencies and professional competencies, and teacher performance. Data analysis techniques used was product moment correlation. The results showed that there was a significant relationship between pedagogic competence and the performance of PJOK teachers. There is a significant relationship between professional competence and the performance of PJOK teachers. There is a significant relationship between pedagogic and professional competence on the performance of PJOK teachers.
\end{abstract}

\section{Keywords: Pedagogic, Professional, and Teacher Performance}

\section{INTRODUCTION}

Sports and health physical education, provide a very meaningful contribution to children's education as a whole, both attitudes, physical and children's knowledge. In order for the learning process to be effective, which is the relationship and activity that occurs between students and educators in achieving educational goals, it should be supported by the competencies possessed by the teacher. Noting that information certainly plays a role in education, namely sports and health physical education teachers contained in UU.No. in 2003 concerning the national education system in article 1 paragraph 6 it was mentioned that "educators are qualified educational staff as teachers, lecturers, counselors, tutors, widyaiswara, tutors, instructors, facilitators, and other designations that are in accordance with their specificities, and participate in implement education[1]. The role of educators as teachers of PJOK greatly determines the achievement of educational goals, namely developing the potential of students. The world of education is needed by teachers who are professional, creative, innovative, have the desire to continue learning, be able to use information technology so that they are able to keep up with the times. The government has applied in Law No. 14 of 2005 concerning Teachers and Lecturers Article 1 paragraph 10, stating "Competence is a set of knowledge, skills, and behaviors that must be owned, internalized, and mastered by the teacher or lecturer in carrying out his professional duties"[2]. Based on the above understanding that the teacher must have the competence of knowledge, skills, and behavior that must be owned, internalized, and mastered by the teacher and lecturer in carrying out their duties. The teacher competency component is contained in Law No. 14 of 2005 concerning Teachers and Lecturers in article 10, paragraph 1 , which states "teacher competence as referred to in article 8 includes, a, pedagogic competence, b, personality competence, c, social competence, and , professional competence "[2]. Based on the understanding that teachers must have competencies including, pedagogical competencies, personality competencies, professional competencies, social competencies. A physical education teacher is required not only to have one competency but to cover all existing competencies such as pedagogic competence, personality competence, professional competence and social competence. If every PJOK teacher is able to master all of these competencies well then the process of learning physical education can be carried out well as well as making competitive students.

Teachers who have competencies will produce good performance, then the objectives of national education will be achieved. From the results of Tris Mardiyiko's research 
showing the results of his research "There is a positive and significant contribution between teacher professional competence and the performance of Salatiga City Middle School teachers", the results of this study show the relationship between teacher competency and teacher performance.

Data collected from West Sumatra LPMP on October 26, 2017 concerning the results of the teacher competency examination (UKG) of sports and health physical education which carried out assignments at Solok City Middle School, from 19 people who attended the UKG who graduated only 1 person $(5.26 \%)$, p. This shows that the PJOK teacher's competency level is still low.

This will affect the teacher's performance in teaching and learning activities conducted by teachers in the classroom and in the field. In the research of Tris Mardiyiko, he showed the results of his research "There is a positive and significant contribution between the professional competence of teachers and the performance of Salatiga City Junior High School teachers" who get simultaneous calculation results of $\mathrm{F}$ is 12,461 with $\mathrm{sig}=$ 0.01 so Ho is rejected means professors' teacher teacher competencies has a contribution to teacher performance.

This means that in the learning process, the task that must be carried out by the teacher is to plan, carry out learning and carry out evaluation of learning. Planning made by the teacher must be in accordance with the concepts of education and learning contained in the curriculum. This plan is a thought about what is done in learning so that a system is created that allows the occurrence of a learning process and can bring students to achieve the expected goals. Furthermore evaluation is carried out to measure the degree of achievement of objectives and to the effectiveness of the learning process implemented. Evaluation is a feedback process that is the basis for improving the learning system. In order for evaluation activities to achieve maximum results, evaluations should be carried out continuously.

In 2013 Curriculum which has the aim to develop the potential of students,curriculum objectives 2013 is to prepare Indonesian people to have the ability to live as individuals and citizens who are productive, creative, innovative, and affective and able to contribute to the life of the world, nation, state and civilization of the world. So the goal of the 2013 curriculum is very - very much preparing for developing the potential of students to be able to contribute to the communityTherefore the teacher is positioned as a facilitator, not as a teacher anymore, the teacher of Physical Education in Sport and Health implements the expected values of attitudes in order to form character students. Teachers have a role in the application of the 2013 curriculum, namely teachers as learning designers, teachers as learning artists, teachers as learning motivators, teachers as learning mediators, and teachers as learning inspirators and must teach about scientific approaches and character learning.

The problem that arises is with regard to teacher performance in planning, implementing and evaluating learning in implementing the 2013 curriculum in sports and health physical education subjects, where the competence of teachers who do not understand well is related to the implementation of the 2013 curriculum especially in the stages of planning, implementing and evaluating learning so that the teacher's performance is reduced in the learning process which implements the 2013 curriculum. A teacher's pedagogic competence must be able to manage learning inside and outside the classroom, personality competence where a teacher must be fair, authoritative, wise and wise, Professional Competence where a teacher must be able to master teaching material, social competence where a teacher must be able to behave with the environment.

Based on information obtained from several teachers who participated in the MGMP PJOK who taught in junior high schools in Solok City and also participated in the UKG PJOK, on October 31, 2017 it could be concluded that PJOK teachers did not understand teacher competencies that must be mastered, from the information stated The teacher does not only know the material to be taught but understands in a wide and deep manner, but at this time the teacher does not understand the material and in the presentation of learning the lack of modifying learning. Not only that a teacher must be a special person, but better for all of his students.

The essence of learning is behavior change. The teacher will be able to change the behavior of students if he has become a good human being, but in reality this is a lot of problems for a teacher. This is evidenced by the amount of news that often appears like "indecent" behavior to students, harsh words uttered by a teacher to students, so students are far from what we expect.

Besides understanding about physical education in PJOK learning is still lacking, the teacher teaches as if as a coach so that teaching such as training, teaching using methods that do not vary, thus causing the emergence of boredom of students in the learning process.

Based on various opinions and studies that have been proposed, it is important to conduct a study to find out Teacher's competencies in the performance of the 2013 curriculum learning process with the title, "relationship of competence with the performance of sports and health physical education teachers in implementing the 2013 curriculum at SOLOK CITY SMP".

\section{METHODOLOGY}

This type of research is correlational research, which aims to determine whether there is a meaningful relationship between predictor variables on variables predicted based on correlation coefficients. The independent variable consists of pedagogic competence and professional competence while the dependent variable is the performance of the PJOK teacher in Solok City Middle School.

The population in this study were Solok City Junior High School teachers who participated in 19 physical education and sports teacher competency exams. "Samples are part of the number and characteristics possessed by the population[3]. In this study the sampling technique used was saturated sampling. All populations are sampled. 
Data collection was carried out with questionnaires used to uncover the formulation of the problem regarding PJOK teacher competence in pedagogic competence, professional competence. The questionnaire model used in this study is in the form of a closed questionnaire with alternative answers already available.

In this study, the data collection technique used a questionnaire. The score to be used in this study is based on the Likert scale. Likert scale has five alternative answers, namely Always / Very Agree, Often / Agree, Sometimes / Doubtfully, Rarely / Disagree, And Never / Strongly Disagree. Scoring of each answer.

The data analysis technique used in this study is to use product moment correlation aims to see the form of the relationship between the independent variable $(\mathrm{X})$ to the dependent variable $(\mathrm{Y})$. The independent variables in this study were pedagogic competencies, PJOK teacher professional competencies and the dependent variable was the PJOK teacher performance in Solok City Middle School.

Data obtained from the questionnaire instrument relating to pedagogic competence, professional competence, will be processed by giving a score of each item.

\section{RESULTS}

From the results of pedagogic competency data carried out on 19 PJOK Solok City teachers, the highest score was 57 and the lowest score was 32. Whereas the range (distance measurement) 5. Based on the group data, the mean is 44 and the deviation is standard (standard deviation) 6. from 19 PJOK teachers in Solok City, which have the results of pedagogic competency data with a score of $>52$ only 2 people $(11 \%)$ and a score of $47-51$ are as many as 3 people (16\%), while scores 42 - 46 is as many as 5 people (26\%) and a score of 37 - 41 is as many as 8 people $(42 \%)$. Furthermore, a score of $<36$ is 1 person $(5 \%)$.

From the results of professional competency data carried out on 19 PJOK Solok City teachers, the highest score was 53 and the lowest score was 31 . Whereas the range (distance measurement) 5. Based on the group data, the mean was 40 and the deviation was standard (standard deviation) 6. from 19 PJOK City Solok teachers, who have the results of professional competency data with a score of $>47$ only 3 people $(16 \%)$ and a score of $43-46$ are 2 people (11\%), while scores $39-42$ are as many as 6 people (32\%) and scores $35-38$ are as many as 5 people $(26 \%)$. Furthermore the score of $<34$ is 3 people $(16 \%)$.

From the results of PJOK teacher performance data conducted on 19 PJOK Solok City teachers, the highest score was 157 and the lowest score was 77 . While the range (measurement distance) 5. Based on the group data, the mean was 117 and standard deviation 20. from 19 PJOK teachers in Solok City, who have the results of PJOK teacher performance data with a score of $>145$ only 1 person (5\%) and a score of $128-144$ as many as 5 people $(26 \%)$, while a score of $111-127$ are 5 people
$(26 \%)$ and scores $94-110$ are 6 people (32\%). Furthermore, the score of $<93$ is 2 people (11\%).

Furthermore, the first hypothesis is that there is a relationship between pedagogic competence and the performance of sports and health physical education teachers. The results of the correlation analysis between pedagogic competencies and the performance of sports and health physical education teachers were calculated to be $0.650>$ rtable 0.456 , meaning that there is a significant relationship between pedagogic competencies with the performance of sports and health physical education teachers in Solok City Middle School, with tcount = 3.5293> t table 1.74. Thus it can be concluded that the proposed hypothesis there is a significant (significant) relationship between pedagogic competence and the performance of sports and health physical education teachers in Solok City Middle School, the truth is empirically accepted.

The second hypothesis is that there is a relationship between professional competence and the performance of sports and health physical education teachers. The results of the correlation analysis between professional competencies and the performance of sports and health physical education teachers were calculated to be 0.6754 > rtable 0.456 , meaning that there is a significant relationship between professional competence and the performance of sports and health physical education teachers in Solok City Middle School. It turns out that tcount $=3.7698>\mathrm{t}$ table 1.74 . Thus it can be concluded that the proposed hypothesis has a significant relationship between professional competence and the performance of sports and health physical education teachers in Solok City Middle School, the truth is empirically accepted.

The third hypothesis is that there is a relationship between pedagogic competencies, professionals with the performance of sports and health physical education teachers. The results of the correlation analysis between pedagigic competencies, professionals with the performance of sports and health physical education teachers obtained $r$ count $0.702>$ rtable 0.456 , meaning that there is a significant relationship between pedagogical competencies, professionals with sports and health physical education teacher performance in Solok City Middle School. With fcount $=7.7945>$ ftabel 3.52 . Thus it can be concluded that the proposed hypothesis has a significant (significant) relationship between pedagogical competencies, professionals with the performance of sports and health physical education teachers in Solok City Middle School, accepted the truth empirically.

\section{DISCUSSION}

Based on the correlation coefficients obtained from the results of data analysis obtained pedagogic competencies of 3.5293> t table 1.74, meaning that there is a significant (meaningful) relationship between pedagogic competence and the performance of sports and health physical education teachers in Solok City Middle School. Indicators of pedagogic competence understanding of students, device design, implementation of PBM, evaluation of 
PBM results, developing students to actualize potential students have less value so that it contributes $42.29 \%$ of teacher performance means pedagogical competence on teacher performance Physical Physical Education and Health worth less, $57.71 \%$ that affects the performance of sports and health Physical Education teachers such as professional, social and personality competencies, can also be seen from the results of teacher competency tests followed by all samples in the results of 19 people following only one person who passed this indicates that competence teachers are very lacking in the end propagating teacher performance. Because teacher competence is closely related to teacher performance, if the teacher's competence is good then the teacher's performance will be good, and vice versa if the teacher's competency is lacking, the teacher's performance in carrying out his duties is far too expected.

teachers who have pedagogical competence and high professional competence can improve teacher performance[4]. It is that pedagogical and professional competence is a business that must be improved.

Moreover, it was obtained from the results of data analysis obtained professional competencies calculated $3.7698>$ rtable 1.75 , meaning that there is a significant relationship between professional competence with the performance of sports and health physical education teachers in Solok City Middle School. Professional competency indicators master scientific substance, master scientific structures and methods, master competency professionally in a global context have less value, so that the contribution given $45.53 \%$ to performance means that teacher professional competence in succeeding teacher performance is categorized as less, $54.47 \%$ influenced by competence pedagogic, social, and personality, other factors are seen from the results of teacher competency exams which were attended by 19 people but only 1 person $(5.26 \%)$ who passed this indicates that teacher competence is still low so it propagates to teacher performance.

Besides, it was also obtained from the results of data analysis obtained pedagogical, professional competencies with fcount $=7.7945>\mathrm{ft}$. 3.52 , meaning that there is a significant (meaningful) relationship between pedagogical competencies, professionals with the performance of sports and health physical education teachers in Solok City Middle School.

teacher performance is the ability of a teacher to carry out tasks with full responsibility, the ability of teacher performance is seen from mastery in planning learning, implementing learning, and assessing the results of learning programs of students[5].

Based on the findings or analysis of the data it turns out that pedagogical, professional competencies are the same - the same as the performance of sports and health physical education teachers in Solok City Middle School have a relationship. Pedagogic and professional competencies are variables that have a very strong relationship and support each other with respect to teacher performance.

However, this finding contributes $49.35 \%$ less, $50.65 \%$ is influenced by other factors, especially social competence and personality is also seen the results of teacher competency tests which were followed by 19 people but only 1 person $(5.26 \%)$ who passed this indicates that teacher competence is still low so propagates on teacher performance. So that teachers experience a low ability to carry out teaching and learning activities so that they propagate the problem in the results of teacher performance.

Many other factors that we also see in the implementation of the teaching and learning process are seen from the age of participants who are still in their 50s who can see the biodata of participants in the attachment, at this age the absorption of material and the level of understanding of a material have difficulty with understanding, what is the level its relevance. There are also those in their 20s, although this youthful appearance also affects due to the experiences gained especially in the process of implementing learning that are still lacking, are they lazy or have never attended trainings held by the school, or the local service. Then this will affect teacher performance.

\section{CONCLUSIONS}

Based on the findings of the research and discussion of the results of the study, it can be concluded that there is a significant relationship between pedagogic competence on the performance of PJOK teachers with $\mathrm{t}$ count $=3.5293>\mathrm{t}$ table $=1.74$. This means that pedagogical competence determines teacher performance, the better the pedagogical competencies the teacher has, the better the teacher's performance.

There is a significant relationship between professional competence on the performance of PJOK teachers with $t$ count $=3.7698>\mathrm{t}$ table $=1.74$. This means that professional competence greatly determines teacher performance, the better the professional competence that the teacher has, the better the teacher's performance.

There is a significant relationship between pedagogical, professional competence on PJOK teacher performance with thitung $=7.7945>\mathrm{t}$ table $=3.52$. This means that pedagogical, professional competence greatly determines teacher performance, the better the pedagogical, professional competencies the teacher has, the better the teacher's performance.

For the Office of Education in this case the role in the Supervisor of each subject, develop teacher competencies as expected by consistently and continuously implementing teacher competency assessments according to the performance appraisal book, both in collaboration with Universities, Education and Culture Research Centers and by introducing roles supervisor's duty.

1. For schools facilitating teacher competency development through training activities, workshops, seminars, book discussions related to activities to explore their potential and sharpen their skills and refine their hearts.

2. For further researchers, the research conducted is very limited in terms of variables, number of samples, place and time of research. So there are still many other variables 
that support the influence of teacher performance in implementing 2013 curriculum on sports and health physical education learning in the city of Solok, it is expected that further researchers are advised to examine other factors that can influence or improve teacher performance.

For teachers Sports and health physical education in order to increase motivation in maximizing performance in the learning process.

\section{REFERENCES}

[1] Law of the Republic of Indonesia No. 20 of 2003 concerning the National Education System, 200, pp 25-33.

[2] Law of the Republic of Indonesia No.14 of 2005 concerning: Teachers and Lecturers. Jakarta: Government of the Republic of Indonesia. 2005, pp 45-65.

[3] Sugiyono. "Educational Research Methods". Bandung: Alfabeta. 2015, pp 118-163.

[4] Salmawati. "Contribution of Pedagogic Competence, Professional Competence and Work Motivation to Junior High School Occupational Teachers in Pati Regency". http: // journal.Unnes.ac.id/sju/index.php/jpes.

Downloaded on 29 November 2017.ISSN 25024477.

[5] Susanto Ahmad. "Management of Teacher Performance Improvement”. Prenadamedia Group. Jakarta. 2016, pp 56-66. 